\title{
Short Communication Flowering of Guadua trinii (Poaceae, Bambusoideae, Bambuseae)
}

\author{
Carolina Guerreiro ${ }^{1,4,5}$, M. Carolina Peichoto ${ }^{2}$ \& Andrea S. Vega ${ }^{3}$
}

\begin{abstract}
Flowering in bamboo is an unusual event. Documenting flowering individuals or populations provides valuable information about bamboo life cycles. Guadua trinii is endemic to northeastern Argentina, southern Brazil, Paraguay and Uruguay. We here report theflowering of this species in native and cultivated stands in Argentina and confirm its flowering cycle to be of 30-33 years.
\end{abstract}

Key words: bamboo, lifecycle, Taquaruçu.

\section{Resumo}

Floração em bambu é um evento incomum. A documentação de indivíduos ou populações em florescimento fornece informações importantes sobre os ciclos de vida do bambu. Guadua trinii é endêmica do nordeste da Argentina, sul do Brasil, Paraguai e Uruguai. Aqui relatamos o florescimento dessa espécie em agregados nativos e cultivados na Argentina, além da confirmação de seu ciclo de floração por 30-33 anos.

Palavras-chave: bambu, ciclo da vida, Taquaruçu.

Bamboos have an extremely wide range of global distribution that occurs in the tropical, subtropical and temperate regions from sea level to $4,000 \mathrm{~m}$ (Judziewicz et al. 1999). Wherever bamboos constitute an important component of the forest, they have profound effects on the dynamics and structure of plant communities (Holz \& Veblen 2006; Campanello et al. 2007; Caccia et al. 2009), and also on the population dynamics of animal species that rely on bamboos for refuge or feeding (Piudo et al. 2005; Gallardo et al. 2008; Areta et al. 2009, 2016; Piudo \& Monteverde 2016).

The most interesting aspect of bamboo biology is their flowering habit. The species that are the most intriguing are those that fall between a state of constant vegetative growth and constant flowering to manifest a cyclic pattern of flowering after long periods of vegetative growth. The flowering cycle of the woody bamboos varies a great deal, from 3 to 120 year intervals (Janzen 1976). The phenomenon of mass flowering is the synchronized flowering at long intervals by a large population (Ramanayake 2006). A more or less fixed, species-specific periodicity to the phenomenon has been described over at least two generations in very few species (Kawamura 1927; Seifriz 1950; Parodi 1955; Janzen 1976; Isagi et al. 2004; Carvalho et al. 2013). Little was known about the intervals between successive mass flowering events of native American bamboos (Parodi 1955; Vega \& Cámara Hernández 2008), until Guerreiro (2014) gathered information from herbarium specimens to reconstruct flowering dates and then estimate flowering cycles of 16 species of woody bamboos native to southern South America.

Any record of a bamboo flowering event, being an individual clump or at a population level, provides valuable information about bamboo life cycles. Regarding this, we recorded the flowering of several clumps of Guadua trinii (Nees) Nees ex Rupr., a woody bamboo species native to northeastern Argentina, southern Brazil, Paraguay and Uruguay. It is found on riversides in the Atlantic forest in dense, almost impenetrable clumps; its scabrous culms are characteristic (Lizarazu et al. 2013; Rúgolo \& Guerreiro 2016). It

\footnotetext{
Instituto de Botánica Darwinion, Labardén 200, B1642HYD, San Isidro, Buenos Aires, Argentina.

${ }^{2}$ Instituto de Botánica del Nordeste (UNNE-CONICET), Facultad de Ciencias Agrarias, Universidad Nacional del Nordeste, Sargento Cabral 2131,3400 Corrientes, Argentina.

${ }^{3}$ Cátedra de Botánica General, Facultad de Agronomía, Universidad de Buenos Aires, Av. San Martín 4453, C1417DSE, Ciudad Autónoma de Buenos Aires, Argentina.

${ }^{4}$ ORCID: <https://orcid.org/0000-0002-6288-3852>

${ }^{5}$ Author for correspondence: cguerreiro@darwin.edu.ar
} 
has been reported its use to build huts, in the paper industry and to make musical instruments (Smith et al. 1981; Keller 2010; Vega \& Rúgolo 2016). A thorough description and an illustration of $G$. trinii can be found in Lizarazu \& Vega (2012) and Vega \& Rúgolo (2016). In this communication, we report the flowering of $G$. trinii in natural and cultivated stands in Argentina and confirm its life span.

Periodical phenological observations led to the record of flowering clumps of natural and cultivated stands of $G$. trinii. All these flowering events were photographed and documented in herbarium specimens kept at BAA and CTES (Thiers, continuously updated).

Flowering of a $G$. trinii cultivated stand was recorded in November 2017 at the Lucien Hauman Botanical Garden of the School of Agronomy of the University of Buenos Aires. Guadua trinii has been

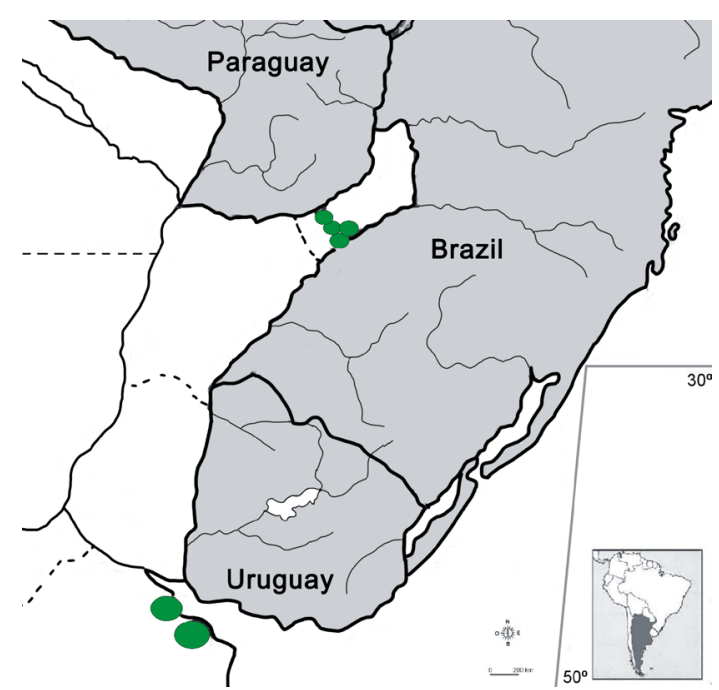

Figure 1 - Map showing the areas where Guadua trinii flowering events were recently recorded.
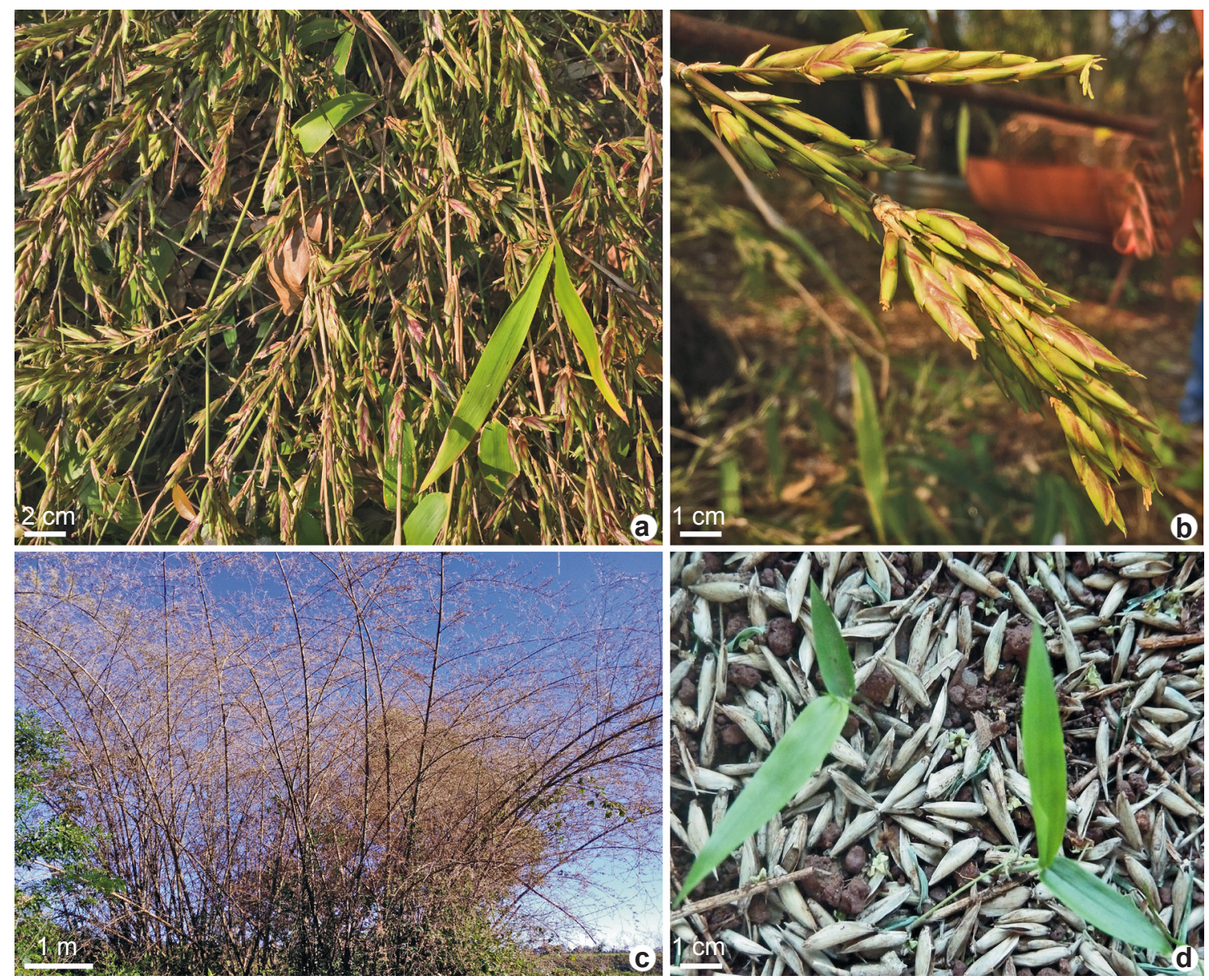

Figure 2 - a-d. Guadua trinii - a,b. pseudospikelets; c. flowering culms of a natural stand; d. seedlings and florets. Photos: a,b: Andrea S. Vega; c,d: Ana María Molina. 
cultivated there for almost 100 years. Seedlings were brought in 1923 by Prof. Lorenzo R. Parodi, a well-known agrostologist, after a flowering event of a natural stand in northern Buenos Aires province, and placed in the Botanical Garden, where they developed vigorously. Then, after 30 years of vegetative growth, Parodi (1955) reported flowering, fructification and death of those clumps, but also regeneration through germination and seedling production. Since then, it has flowered and died cyclically in a 30-33 year period, along with individuals in natural stands occurring far away, perpetuating itself and showing one of the most intriguing phenomenon in bamboo biology.

At the same time, flowering of $G$. trinii was observed in a natural stand of Ribera Norte Nature Reserve, a protected area in northern Buenos Aires province, the southernmost part of its natural distribution (C. Larsen, pers. comm.). Soon after, massive flowering events were recorded in Misiones province, particularly in the southern departments of the province: Candelaria, L. N. Alem, San Javier and Oberá (Keller, pers. comm.; Fig. 1). However, there are still many natural populations of $G$. trinii not showing signs of entering a reproductive phase, especially in the northernmost part of Misiones province (A. Mantese, pers. comm.). These populations may be expected to flower in the coming months, since a single flowering event can last up to 2 years (Parodi 1955; Lizarazu et al. 2013).

During its reproductive stage, G. trinii clumps were almost leafless, with a high production of pseudospikelets (Fig. 2a,b). At caryopsis maturity, the whole clump turned to a stramineous colour (Fig. 2c). Caryopses formation and seedling development were also recorded (Fig. 2d).

Material examined: ARGENTINA. BUENOS AIRES: Cultivado en el Jardín Botánico de la Facultad de Agronomía, 15.IX.2017, fl., A. S. Vega 28 (BAA). MISIONES: Leandro N. Alem, ruta $14 \mathrm{~km} .642$, antes de la gran plantación de pinos, 21.X.2017, fl., A. M. Molina

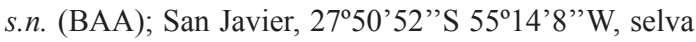
en bajo, caña leñosa, 16.VIII.2017, fl., H. Keller \& J. L. Rojas 13619 (CTES).

\section{References}

Areta JI, Bodrati A \& Cockle K (2009) Specialization on Guadua bamboo seeds by three bird species in the Atlantic forest of Argentina. Biotropica 41: 66-73.

Areta JI, Bodrati A \& Cockle K (2016) Un panorama de las aves especialistas en bambúes de la Argentina. In: Rúgolo ZE. Bambúes leñosos nativos y exóticos de la Argentina. Trama S.A., Buenos Aires. Pp. 221-236.
Caccia FD, Chaneton EJ \& Kitzberger T (2009) Direct and indirect effects of understorey bamboo shape tree regeneration niches in a mixed temperate forest. Oecologia 161: 771-780.

Campanello PI, Gatti MG, Ares A, Montti L \& Goldstein $\mathrm{G}$ (2007) Tree regeneration and microclimate in a liana and bamboo-dominated semideciduous Atlantic forest. Forest Ecology and Management 252:108-117.

Carvalho AL, Nelson BW, Bianchini MC, Plagnol D, Kuplich TM \& Daly DC (2013) Bamboo-dominated forests of the southwest Amazon: detection, spatial extent, life cycle length and flowering waves. PLoS ONE 8:e54852. DOI: 10.371/ journal.pone.0054852

Gallardo A, Montti L \& Bravo SP (2008) Efectos del tacuarembo (Chusquea ramosissima, Poaceae) sobre el proceso de dispersión de semillas en la Selva Misionera. Ecología Austral 18: 347-356.

Guerreiro C (2014) Flowering cycles of woody bamboos native to southern South America. Journal of Plant Research 127: 307-313.

Holz A \& Veblen TT (2006) Tree regeneration responses to Chusquea montana bamboo die-off in a subalpine Nothofagus forest in the southern Andes. Journal of Vegetation Science 17:19-28.

Isagi Y, Shimada K, Kushima H, Tanaka N, Nagao A, Ishikawa T, Onodera H \& Watanabe S (2004) Clonal structure and flowering traits of a bamboo (Phyllostachys pubescens (Mazel) Ohwi) stand grown from a simultaneous flowering as revealed by AFLP analysis. Molecular Ecology 13: 2017-2021.

Janzen DH (1976) Why bamboos wait so long to flower. Annual Review of Ecology and Systematics 7: 347-391.

Judziewicz EJ, Clark LG, Londoño X \& Stern MJ (1999) American bamboos. Smithsonian Institution Press, Washington DC. 392p.

Kawamura S (1927) On the periodical flowering of the bamboo. Japanese Journal of Botany 3: 335-342.

Keller HA (2010) Plantas usadas por los guaraníes de Misiones (Argentina) para la fabricación y el acondicionamiento de instrumentos musicales. Darwiniana 48: 7-16.

Lizarazu MA, Rúgolo de Agrasar ZE \& Vega AS (2013) A new species of Guadua (Poaceae, Bambusoideae, Bambuseae) and synopsis of the genus in Argentina and neighboring regions. Systematic Botany 38: 1062-1075.

Lizarazu MA \& Vega AS (2012) Guadua. In: Zuloaga FO Rúgolo de Agrasar ZE \& Anton AM (eds.) Flora argentina. Plantas vasculares de la República Argentina. Monocotiledoneae: Poaceae: Aristidoideae-Pharoideae, Graficamente Ediciones, Córdoba. Pp. 59-63.

Parodi LR (1955) La floración de tacuara brava (Guadua trinii). Revista Argentina de Agronomía 22: 134-136. 
Piudo L, Monteverde M, Gonzalez Capria S, Padula P \& Carmanchahi P (2005) Distribution and abundance of sigmodontine rodents in relation to hantavirus in Neuquen, Argentina. Journal of Vector Ecology 30: 119-125.

Piudo L \& Monteverde M (2016) Efectos ecoepidemiológicos de la floración masiva de la caña Colihue. In: Rúgolo ZE. Bambúes leñosos nativos y exóticos de la Argentina. Trama, Buenos Aires. Pp. 179-188.

Ramanayake SMSD (2006) Flowering in bamboo: an enigma! Ceylon Journal of Sciences (Biological Sciences) 35: 95-105.

Rúgolo ZE \& Guerreiro C (2016) Distribución de los bambúes leñosos nativos de la Argentina. In: Rúgolo ZE. Bambúes leñosos nativos y exóticos de la Argentina. Trama, Buenos Aires. Pp. 19-24.
Seifriz W (1950) Gregarious flowering of Chusquea. Nature 22: 635-636.

Smith LB, Wasshausen DC \& Klein RM (1981) Flora Ilustrada Catarinense. I parte. Gramíneas. Ioesc, Santa Catarina. Pp. 29-34.

Thiers (2018) Index Herbariorum: a global directory of public herbaria and associated staff. New York Botanical Garden's Virtual Herbarium, New York. Available at $<$ http://sweetgum.nybg.org/science/ih $>$.

Vega AS \& Camara Hernandez J (2008) La floración de Guadua chacoensis (Poaceae, Bambusoideae, Bambuseae). Revista de la Facultad de Agronomía UBA 28: 107-110.

Vega AS \& Rúgolo ZE (2016) Guadua. In: Rúgolo ZE. Bambúes leñosos nativos y exóticos de la Argentina. Trama, Buenos Aires: 99-112. 